\title{
DAMPAK EFIKASI DIRI TERHADAP PROSES \& HASIL BELAJAR MATEMATIKA \\ (The Impact Of Self-Efficacy On Mathematics Learning \\ Processes and Outcomes)
}

\section{Wahyu Fitra Ningsih ${ }^{1}$ dan Isnaria Rizki Hayati ${ }^{2}$}

\author{
Program Studi Pendidikan Matematika, Tarbiyah, Universitas Islam Sultan Syarif \\ Kasim Riau, Pekanbaru \\ Email : Wahyufitraningsih07@gmail.com
}

\begin{abstract}
Abstrak
Kompetensi dalam pemecahan masalah matematika tentunya harus dimiliki oleh setiap siswa dalam menyelesaikan soal-soal matematika. Banyak persepsi di kalangan peserta didik yang menyatakan bahwa matematika adalah pelajaran yang sulit. Oleh karena itu dalam hal ini, efikasi diri sangat diperlukan untuk mengatasi masalah tersebut. Efikasi diri merupakan keyakinan yang dimiliki oleh seseorang tentang seberapa besar kemampuan yang dimilikinya untuk menyelesaikan suatu tugas pembelajaran. Siswa dengan efikasi diri yang baik akan berhasil dalam pencapaian hasil kegiatan belajarnya, dan sebaliknya siswa dengan efikasi diri yang rendah maka hasilnya siswa tersebut akan dengan cepat menyerah dalam proses belajarnya sehingga hasil yang didapat pun tidak akan maksimal. Jadi dari hasil analisis tersebut diperoleh kesimpulan bahwa efikasi diri memiliki dampak yang positif dan signifikan terhadap hasil belajar siswa.
\end{abstract}

Kata kunci: Efikasi diri, Proses, Hasil, Matematika

\section{PENDAHULUAN}

Pendidikan merupakan suatu proses perubahan pola pikir manusia dalam mendapatkan ilmu pengetahuan yang akan bermanfaat bagi kehidupan. Keberhasilan dalam pendidikan akan diraih oleh suatu bangsa apabila ada usaha untuk meningkatkan kualitas pendidikan bangsa itu sendiri. Dalam hal meningkatkan kualitas suatu pendidikan, matematika memegang peranan penting. Matematika digunakan oleh setiap individu sebagai sarana pemecahan masalah dalam kehidupan sehari-hari. Selain berperan penting dalam kehidupan sehari-hari, matematika juga merupakan salah satu mata pelajaran wajib yang dipelajari oleh setiap siswa di berbagai jenjang pendidikan mulai dari sekolah dasar (SD) sampai dengan perguruan tinggi, baik itu pendidikan umum maupun pendidikan kejuruan. Namun, karakteristik matematika yang abstrak dan sistematis dalam pembelajaran membuat matematika sulit dipahami oleh siswa.

Vandini (2015), mengemukakan bahwa matematika dianggap sebagai pelajaran yang paling sulit dan menakutkan bagi siswa diantara pelajaranpelajaran lainnya sehingga siswa tidak begitu berminat untuk belajar matematika, 
mereka cenderung hanya mengikuti proses pembelajarannya saja, tetapi tidak menanamkan dan mempelajarinya dengan sungguh-sungguh sehingga aktivitas siswa tidak nampak dalam proses pembelajaran dan berdampak buruk bagi hasil belajarnya.

Kegiatan belajar dan mengajar sasarannya adalah hasil belajar. Hasil belajar adalah salah satu cara untuk mengukur seberapa jauh siswa memahami pembelajaran. Tingkatan kemampuan siswa dalam suatu lembaga pendidikan dapat ditunjukkan dengan hasil tes yang diberikan oleh guru dalam proses pembelajaran. Secara psikologis ada dua macam aspek internal yang mempengaruhi hasil belajar siswa, yaitu faktor aspek kognitif dan aspek afektif (Slameto, 2013). Salah satu aspek afektif yang dapat mempengaruhi hasil belajar siswa adalah self-efficacy. Efikasi diri atau self-efficacy yaitu keyakinan atas kompetensi diri. Efikasi diri merupakan keyakinan seseorang untuk mengendalikan kemampuan dirinya sendiri yang diwujudkan dengan serangkaian tindakan dalam memenuhi tuntutan-tuntutan dalam hidupnya.

Siswa dengan self-efficacy yang tinggi akan yakin bahwa mereka sanggup melakukan sesuatu untuk mengubah hal-hal di sekitarnya, sedangkan siswa dengan efikasi diri yang rendah akan menganggap dirinya tidak sanggup mengerjakan segala sesuatu yang ada disekitarnya. Dalam situasi yang sukar, siswa dengan efikasi diri yang rendah akan cenderung mudah menyerah. Sementara siswa dengan self-efficacy yang tinggi akan berusaha lebih keras untuk melewati tantangan yang ada. Oleh karena itu, efikasi diri (self-efficacy) sangat berdampak pada hasil belajar siswa.

\section{PEMBAHASAN}

Teori efikasi diri (Self-efficacy) juga dikenal sebagai teori kognitif sosial, yang dikembangkan oleh professor dari Universitas Stanford, Albert Bandura (1977). Menurut Bandura (1997:3), efikasi diri adalah dasar utama dari tindakan. Efikasi diri mengacu pada keyakinan siswa terhadap kecakapannya dalam mengatur dan melaksanakan serangkaian tindakan untuk mencapai hasil yang ditetapkan. "Self-efficacy is a self-confidence of the extent of individual estimates his ability in execute a task or action required to achieve." Bandura ((Qudsyi \& Irma, 2016) yang berarti efikasi diri merupakan kepercayaan diri yang dimiliki seseorang tentang sejauh mana orang tersebut mengerahkan kemampuannya dalam melaksanakan tugas atau sejauh mana tindakan yang dibutuhkan untuk mencapainya.

Efikasi diri (Self-efficacy), merupakan salah satu aspek penunjang yang sangat berarti dalam proses pembelajaran karena akan mempengaruhi pencapaian hasil belajar (Bandura dalam Santrock, 2008). Masalah yang umumnya dihadapi siswa dalam belajar adalah mengenai kurangnya minat sebagian siswa pada mata pelajaran tertentu. Matematika menjadi salah satu mata pelajaran wajib di sekolah memiliki ciri-ciri yang abstrak, teoritis, sarat dengan lambang-lambang dan rumus-rumus yang membingungkan, yangmana hal tersebut didasarkan atas pengalaman kurang menyenangkan ketika proses belajar matematika di sekolah, yang ikut menciptakan anggapan negatif siswa terhadap matematika (Sriyatno,2017). Menurut Maddux (2016) Efikasi diri 
menentukan bagaimana pilihan sikap kita, usaha yang kita keluarkan, kegigihan kita dalam menghadapi kesulitan, dan pengalaman emosional kita.

Keterkaitan antara efikasi diri dengan hasil belajar siswa dikemukakan oleh Bandura yaitu siswa dengan efikasi diri yang tinggi akan percaya bahwa mereka mampu menyelesaikan segala tugas yang ada meskipun mendapatkan tugas yang sulit. Bandura (Wilson \& Janes, 2008) menyatakan bahwa perasaan positif yang tepat tentang efikasi diri dapat mempertinggi prestasi, meyakini kemampuan, mengembangkan motivasi internal, dan memungkinkan siswa untuk meraih tujuan yang lebih menantang. Hal ini berarti, minat sebagai salah satu faktor pendorong siswa mampu melakukan sesuatu untuk mencapai keberhasilannya. Sementara siswa dengan efikasi diri yang rendah akan memiliki pemikiran bahwa dirinya tidak mampu mengerjakan segala tugas-tugas yang ada dalam proses belajar siswa tersebut. Rendahnya self-efficacy siswa pada mata pelajaran matematika diindikasikan dengan banyaknya siswa yang tidak ingin mencoba lebih banyak untuk mengerjakan soal matematika, dan cenderung cepat menyerah ketika munculnya efikasi diri yang baik pada diri siswa.

Pentingnya pengembangan efikasi diri siswa dalam pemecahan masalah matematika dikarenakan: (1) Proses pembelajaran matematika di kelas sangat dipengaruhi oleh efikasi diri siswa terhadap pelajaran matematika (Shadiq, 2007: 1), (2) Efikasi diri siswa membentuk kemampuan matematika siswa dalam pemecahan masalah matematika (Bandura, 1993: 119), (3) Pelajaran matematika diasumsikan oleh kebanyakan siswa sebagai pelajaran yang sulit, membuat stress, dan membosankan, dimana dengan efikasi diri yang tinggi permasalahan tersebut bisa dikurangi bahkan dapat dihilangkan oleh siswa itu sendiri (Leonard dan Supardi, 2010: 342) .

Bandura (1997), Self-efficacy dapat diperoleh, dipelajari dan dikembangkan dari empat sumber informasi, yang merupakan faktor-faktor yang mempengaruhi self-efficacy. Keempat faktor tersebut adalah pengalaman keberhasilan dan pencapaian prestasi, pengalaman orang lain, persuasi verbal, keadaan fisiologis dan psikologis. Bandura (1997) juga mengungkapkan perbedaan efikasi diri yang dimiliki oleh setiap individu terletak pada tiga kognisi atau dimensi, yaitu:

1) Magnitude atau tingkat kesulitan tugas. Hal ini berhubungan dengan kesulitan tugas dimana individu akan memilih tugas berdasarkan pada tingkat kesulitannya.

2) Generality atau generalitas, ini berkaitan erat dengan luas bidang tingkah laku. Dimana seseorang merasa yakin akan kemampuannya berdasarkan pengalaman sebelumnya.

3) Strength atau kekuatan, ini berhubungan dengan keyakinan seseorang tentang sejauh mana ia yakin akan dapat melaksanakan tugas dengan sebaik-baiknya.

Dalam hal ini, Bandura (1997) mengingatkan bahwa self-efficacy tidak berkaitan dengan kecakapan yang dimiliki oleh seseorang, tetapi berkaitan dengan keyakinan mengenai hal yang dapat dilakukannya dengan kecakapan yang ia miliki seberapa pun besarnya. 
Hasil belajar adalah salah satu cara untuk mengukur seberapa jauh siswa memahami pembelajaran. "Learning Outcomes are the knowledge, skills, attitudes and habits of mind that students develop and take with them." Suskie (Ohia, 2015). Hasil belajar merupakan gambaran tentang bagaimana siswa memahami materi pelajaran yang disampaikan oleh guru yang berupa nilai yang diperoleh siswa dari hasil tes, tugas maupun penilaian dari sikap dan kepribadian siswa. Menurut Purwanto (2013), hasil belajar seringkali digunakan sebagai ukuran untuk mengetahui seberapa jauh siswa menguasai materi yang telah diajarkan. Oleh karena itu, hasil belajar matematika adalah gambaran tingkatan perubahan, pencapaian, pemahaman, dan keterampilan siswa dalam menyelesaikan masalah matematika setelah melalui proses belajar mengajar yang terlihat pada nilai yang didapat dari hasil tes dan hasil belajar. Namun permasalahannya adalah hasil belajar matematika pada jenjang pendidikan dasar dan menengah di Indonesia secara umum masih relative rendah jika dibandingkan dengan mata pelajaran lainnya. Hal ini terlihat pada salah satu hasil survey internasional yang diikuti oleh Indonesia yaitu TIMSS (Trends in International Mathematics and Science Study).

Berdasarkan hasil survey TIMSS pada tahun 2015 (Puspendik, 2016:01) dalam bidang matematika dari 50 negara Indonesia menduduki peringkat ke-45 dengan skor 397, dimana skor ini masih jauh dari standar yang digunakan TIMSS yaitu 500. Dari data tersebut dapat terlihat bahwa kemampuan pemecahan masalah matematis peserta didik Indonesia termasuk dalam kategori rendah. Yang berarti bahwa peserta didik cenderung belum memiliki kompetensi berupa kepercayaan dan penghargaan terhadap kemampuan yang dimilikinya atau selfefficacy yang dimiliki peserta didik masih tergolong rendah.

Dalam menyikapi masalah tersebut, maka diperlukan adanya perbaikan didalam proses pembelajaran di kelas. Terutama yang berkaitan dengan cara guru berkomunikasi, komunikasi guru yang efektif dapat membantu meningkatkan proses pembelajaran di kelas. Dalam hal ini guru diharapkan mampu untuk mendorong siswa mengembangkan efikasi diri yang tinggi selama memfasilitasi siswa mengikuti pembelajaran. Hal ini penting mengingat bahwa efikasi diri yang tinggi akan berdampak terhadap kesenangan siswa dalam belajar.

Efikasi diri merujuk pada kekuatan keyakinan diri individu untuk mampu melakukan sebuah tugas atau kegiatan, serta berpengaruh kepada motivasi dan prestasinya. Keyakinan dan persepsi negatif pada pelajaran matematika dapat di rekonstruksi kembali, yaitu dengan mengubah persepsi dan keyakinan individu dengan cara meyakinkan tiap individu siswa atas kemampuannya yang dikuatkan dengan banyak belajar dan latihan mengerjakan soal-soal matematika. Saat siswa telah memiliki keyakinan terhadap kemampuan yang ia miliki, maka keyakinannya tersebut akan menumbuhkan motivasi belajarnya dan juga meningkatkan prestasinya.

Kemudian cara belajar yang baik juga merupakan salah satu faktor yang dapat meningkatkan hasil belajar siswa, seperti yang dikemukakan oleh Maryati (2013), cara belajar memberikan ciri dalam aktivitas belajar yang dilakukan siswa yang pada gilirannya dapat mempengaruhi hasil belajar siswa. Keyakinan akan kemampuannya merupakan sikap positif yang dapat memicu pencapaian hasil 
belajar yang optimal, dengan sikap optimis siswa akan sukses dalam belajarnya (Hidayat \& Sariningsih, 2018). Sehingga dapat ditarik kesimpulan bahwa selfefficacy adalah hal yang sangat penting dimiliki oleh siswa. Dalam penelitian yang dilakukan oleh Rezki Wahyu Hidayat dengan judul Pengaruh Efikasi Diri (SelfEfficacy) Terhadap Kemampuan Pemecahan Masalah Matematika, hasil penelitiannya menunjukkan bahwa terdapat pengaruh yang signifikan antara efikasi diri (self-efficacy) terhadap pemecahan masalah matematika. Hal ini berarti dalam menyelesaikan pemecahan masalah matematika, semakin tinggi efikasi diri yang dimiliki peserta didik, maka semakin mudah mereka menyelesaikannya. Karena efikasi diri akademik, merupakan hal yang akan menjadi penentu suksesnya perilaku akademik di masa yang akan datang (Alwisol, 2004).

Ormod (Raditiana,2015) menjelaskan beberapa upaya dalam rangka meningkatkan efikasi diri, yaitu:

1) Mengajarkan pengetahuan dan kemampuan dasar sampai dikuasai;

2) Memperlihatkan catatan kemajuan siswa tentang keterampilanketerampilan rumit;

3) Memberikan tugas yang menunjukkan bahwa siswa dapat berhasil hanya dengan kerja keras dan pantang menyerah;

4) Meyakinkan siswa bahwa dirinya bisa sukses, sambil menunjukkan contoh teman sebaya yang sebelumnya sukses melakukan hal yang sama;

5) Memperhatikan model rekan-rekan sebaya yang sukses kepada para siswa

6) Memberikan tugas dan kompleks dalam aktivitas-aktivitas kelompok kecil.

Dalam hal ini seorang guru amat berperan penting, guru perlu mengetahui dan mengarahkan agar siswa memiliki efikasi diri sehingga siswa mampu memecahkan masalah matematika. Sebagai bentuk keyakinan terhadap diri untuk melakukan tugas pada sebuah tingkatan pendidikan tertentu, efikasi diri akan membentuk sugesti dan persepsi atas keberhasilan dalam menyelesaikan tugas yang diberikan. Sehingga dapat disimpulkan bahwa efikasi diri telah terbukti secara empiris memiliki peran penting sebagai pencetus motivasi belajar siswa. Tinggi rendahnya self-efficacy yang dimiliki oleh siswa akan berpengaruh terhadap pilihan aktivitas yang dilakukan, tingkat usaha yang dilakukan, tingkat kegigihan belajar dan tingkat reaksi emosional yang dikeluarkan. Keyakinan atas kemampuan diri dalam menyelesaikan tugas atau aktivitas yang dibebankan akan mempengaruhi cara bertindak individu yang bersangkutan.

\section{SIMPULAN}

Efikasi diri merupakan faktor yang kuat mempengaruhi hasil belajar matematika siswa. Self-efficacy siswa terhadap matematika adalah keyakinan diri siswa akan kemampuannya dalam menyelesaikan masalah, menyelesaikan tugas tanpa membandingkan dengan kemampuan orang lain sehingga dapat mencapai keberhasilan dalam prestasi belajar matematika disertai dengan rasa yakin terhadap usaha yang dilakukan, pilihan yang telah ditentukan, dan memiliki ketekunan. Adapun indikator self-efficacy yang diamati meliputi keyakinan 
dengan kemampuan diri yang dimiliki, perasaan mampu untuk memecahkan masalah matematika, perasaan mampu untuk melaksanakan tugas, perasaan mampu untuk mencapai target prestasi belajar, dan yakin dengan usaha yang dilakukan.

\section{DAFTAR PUSTAKA}

Amir, H. (2016). Kolerasi Pengaruh Faktor Efikasi Diri dan Manajemen Diri Terhadap Motivasi Berprestasi Pada Mahasiswa Pendidikan Kimia Universitas Bengkulu, UNIB Scholar Repository, 10(4), 336-342.

Darkonah. (2015). Bimbingan Kelompok untuk Meningkatkan Efikasi Diri Siswa SMPN 5 Satu Atap Tanjung Brebes, Skripsi. Fakultas Dakwah dan Komunikasi, Universitas Islam Negeri Sunan Kalijaga, Yogyakarta.

Dewi, A. F., Adi Atmoko., \& Triyono. (2016). Keefektifan Teknik Self Instruction dalam Konseling Kognitif-Perilaku untuk Meningkatkan Efikasi Diri Sosial Siswa SMKN 2 Malang. Jurnal Kajian Bimbingan dan Konseling, 1(4), 172178. ISSN: $2548-4311$

Fitriana, S., Hisyam, I., dan Suwardi, A. (2015). Pengaruh Efikasi Diri, Aktivitas, Kemandirian Belajar dan Kemampuan Berpikir Logis Terhadap Hasil Belajar Matematika Pada Siswa Kelas VIII SMP. Journal of EST, 1 (2), 8610. ISSN : 2460-1497.

Hendriana, H., \& Gida, K. (2019). Self-Efficacy dan Kemampuan Komunikasi Matematis Siswa SMP. Jurnal Nasional Pendidikan Matematika, 3(1), 153264. DOI : 10.33603.

Jumalia. (2018). Pengaruh Kepercayaan Diri dan Kemampuan Komunikasi Matematika Terhadap Hasil Belajar Matematika Siswa Kelas VIII SMP Negeri 5 Majene. Skripsi. Fakultas Matematika dan Ilmu Pengetahuan Alam, Universitas Negeri Makassar.

Khofifah, A., Afrizal, S., \& Yarmis, S. (2017). Permasalahan yang Disampaikan Siswa Kepada Guru BK/Konselor. Jurnal education, 3(1), 45-52. ISSN : 2476-9886

Monika, \& Adman. (2017). Peran Efikasi Diri dan Motivasi Belajar dalam Meningkatkan Hasil Belajar Siswa Sekolah Menengah Kejuruan. Jurnal Pendidikan Manajemen Perkantoran, 2(2), 219-226. E-ISSN : 2656-4734. http://ejournal.upi.edu/index.php/jpmanper/article/view/00000.

Novferma, N. (2016). Analisis Kesulitan dan Self Efficacy Siswa SMP Dalam Pemecahan Masalah Matematika Berbentuk Soal Cerita. Jurnal Riset Pendidikan Matematika, 3(1), 76-87. DOI : http://dx.doi.org/10.21831/jrpm.v3il.10403.

Septiani, T., Muhammad Abdussalam, H., Heris, H., \& Ika, W.A. (2018). Pengaruh Self Confidence dan Self Efficacy Terhadap Kemampuan Berpikir Kreatif Matematis Siswa SMP. Jurnal Pembelajaran Matematika Inovatif, 1(2), 185-192. DOI : 10.22460

Somawati. (2018). Peran Efikasi Diri (Self-Efficacy) terhadap Kemampuan Pemecahan Masalah Metematika. Jurnal Konseling dan Pendidikan, 6(1), 39-45. DOI : https://doi.org/10.29210/118800.

Sopiyah. (2016). Peningkatan Self-Efficacy Pada Siswa Melalui Konseling Cognitive Behavioral. Jurnal Bimbingan dan Konseling Indonesia, 1(2), 26- 
28. DOI : http://dx.doi.org/10.26737/jbki.v1i2.103.

Subaidi, A. (2016). Self-Eficacy Siswa dalam Pemecahan Masalah Matematika. Jurnal Sigma, 1(2), 64-68.

Sunawan., Sugesti, Y., Ahmad, Y., Trubus, I. K., Catharina, T. A., Mulawarman., \& Afriyadi, S. (2017). Dampak Efikasi Diri Terhadap Beban Kognitif dalam Pembelajaran Matematika dengan Emosi Akademik Sebagai Mediator. Jurnal Psikologi, 44(1), 28-38. DOI : 10.22146.

Wahyuni, S. D. (2016). Pengaruh Efikasi Diri, Cara Belajar, Persepsi Siswa Tentang Komunikasi Guru dan Persepsi Siswa Tentang Perhatian Orangtua Terhadap Hasil Belajar Siswa Kelas XI MAN di Kota Palu. Jurnal Matematika dan Pembelajarannya, 2(2), 21-42. ISSN : 2303-0992.

Widyastuti., Agung, P. W., Wayan, R., dan Rini Rita T. Marpaung., (2019). Minat Siswa Terhadap Matematika dan Hubungannya Dengan Metode Pembelajaran dan Efikasi Diri. Jurnal Pendidikan Matematika, 13(1), 83100. ISSN : 1978-0044. 